K. Chakraborty'

\title{
Development of financial market activities and economic growth: A cross-country evidence
}

\begin{abstract}
This paper examines the relationship between insurance market development and economic growth and various conditions that affect the insurance-growth nexus. The conditions tested are degree of financial development, banking activity, and demographic profile of a country. The empirical study uses cross country panel data from 90 countries for the period 1995 to 2015 and applies Hausman-Taylor random effect model. The main findings confirm a positive non-linear relationship between insurance market development and economic growth. The study also finds the impact of banking and stock market developments reduce the positive effect of insurance market activities on economic growth implying these activities are substitutes for insurance market promoting economic growth. Two major contributions for this study are: (i) it tests the hypothesis that the impact of insurance development on economic growth is non-linear, which implies at a higher level of economic development increased insurance spending would reduce economic growth; and (ii) it tests the hypothesis whether banking development and stock market activities are substitute or complement to insurance market development in the economic growth process.
\end{abstract}

Keywords: insurance; development; economic growth; dynamic; panel data; nonlinear.

JEL classification: C23; E44; O16; G22.

\section{Introduction}

7 he fundamental idea that a strong financial sector plays a vital role promoting economic growth was originally pioneered by Schumpeter (1934). According to Schumpeter, financial development is important for growth because financial structure offers financial intermediaries the opportunity to transfer funds to most innovative entrepreneurs. Goldsmith (1969) provides the empirical evidence of a positive correlation between the size of the financial depth and long-run economic growth. However, his study did not provide the causal relationship going from financial depth (i.e., banking services) to economic growth. As a provider of risk transfer/ indemnification and financial intermediary, insurance market activity enhances economic growth by providing businesses with the ability to manage risk more efficiently. Insurance activities provide new capital accumulation and mobilize domestic savings into productive investments. With improved financial services, these investors can access diversified investment portfolios, which facilitate their willingness to invest in high-risk and/or high-productivity projects. For example,

1 Chakraborty, Kalyan — University of Tampa, Florida, US; kchakraborty@ut.edu. 
risk averse individuals may buy high expense items such as, automobile, and real estate because insurance provides risk transfer and indemnification services. Hence, insurance coverage has positive externalities from increased consumptions, profits, and employment within the insurance sector as well as other sectors in the economy. Without access to product liability insurance, pharmaceutical firms would be reluctant to develop and market life-saving drugs.

Webb et al. (2002) model the impact of life and nonlife insurance on economic growth using a neoclassical Solow-Swan model. The model states production growth from labor, capital, and technology augmented by financial activities of property/liability insurers and life insurers, including banking activities may measure the differences in productivity and investments based on institutional factors and savings rate. The neoclassical growth model relies on representative household, such that the demand side of the economy is generated by the optimizing behavior of a single household. Contrary to that assumption, Acemoglu (2007) developed the overlapping generation (OLG) growth model that captures potential interaction of different generations of individuals in the marketplace. Decisions made by the older generations will affect the price faced by the younger generations. The OLG model assumes households in the economy may be 'infinitely lived' (overlapping generations) with full altruism linking generations within the household when making decisions to purchase products/services such as, life insurance policy. Lu and Yanagihara (2013) use two-period overlapping generations model and find economic growth rate is higher when there is life insurance available and the rate of time preference or the productivity of human capital is low. However, empirical estimation of OLG growth model is beyond the scope and purpose of this study.

Compared with wide coverage of the effect of banking and stock market development on economic growth the studies on insurance market development and economic growth received much less attention. The prominence of insurance-growth nexus has grown over the last two decades due to increasing share of insurance sector in aggregate financial sector globally. According to (Swiss Re, 2018) world GDP growth between 2008 and 2017 has increased by 3.39 percent and the world insurance premium has increased by 1.2 percent. However, during the same period the GDP growth for the emerging and developing countries has increased by 5.12 percent compared with 2.5 percent for the advanced economies. The premium growth for the same period for emerging and developing countries has increased by 7.9 percent and for advanced economies premium growth is only 0.1 percent. However, the advanced countries share 78.08 percent of global premium compared with 21.92 percent for emerging and developing countries.

Insurance market activity not only contributes to economic growth directly but indirectly through complementarities with banking sector and stock market (Arena, 2008). For example, risk protection offered by insurance sector encourages bank borrowings by reducing the market cost of capital for the companies (Grace, Rebello, 1993; Zou, Adams, 2006). Moreover, insurance companies may promote stock and bond market development (capital market deepening) investing funds (savings) raised by contractual savings products in stocks and equities (Catalan et al., 2000; Skipper, 1997). Development of stock market may also reinforce development of insurance activity because, for life insurance market that matches long-term liability to long-term assets, liquid capital markets help insurance companies invest their resources collected through premiums (Arena, 2008).

In this background, the purpose of this study is to examine the relationship between insurance market development (life and nonlife) and economic growth at the same time assess whether the insurance activities are complementary to banking sector and stock market developments. This paper adds to our body of knowledge as it expands the analysis to a larger panel dataset ( 90 countries, 
1995-2015) on the insurance-growth nexus. We also apply a robust econometric method HausmanTaylor (1981) random effect model for estimating the impact of life and non-life insurance market development on economic growth. Two major contributions for this study are:

(i) It tests the hypothesis that the impact of insurance development on economic growth is nonlinear. Which implies at a higher level of economic development increased insurance spending would reduce economic growth.

(ii) It tests the hypothesis whether banking development and stock market activities are substitute or complement to insurance market development in the economic growth process.

The empirical study estimates a basic regression model using annual per capita GDP growth as a dependent variable and life and non-life insurance activities (penetration and density) and several macroeconomic control variables as independent variables. The results show how different macroeconomic factors interact the relationship between insurance market development and economic growth. In addition to the basic macroeconomic variables, we add three sets of conditional variables such as, demographic, economic, and financial variables and examine their impact on insurance market and economic growth. The study finds that insurance density and penetration positively affect economic growth and the relationship is non-linear. This study also finds that the impact of banking development reduces the positive effect of insurance market on economic growth and the impact of stock market activity, though positively related to economic growth acts as complement to insurance market in the growth process.

The remainder of the study organized as follows. Section 2 reviews the background and literature for this study. Section 3 provides the empirical model and the methodology. The discussion on the description and sources of dataset is in Section 4. Section 5 reports the empirical results. The final section draws the summary and conclusions.

\section{Background and literature review}

The literature on financial development and economic growth is vast. Studies generally found that economic growth and prosperity for a country determined by the efficient and developed financial sector (Ang, 2008; Freytag, Fricke, 2017). However, Carter and Dickinson (1992) find institutional and political environments influence the insurance market activities. Chang and Lee (2012) find institutional factors such as, civil liberties, political stability, government effectiveness, regulatory equality, rule of law, and control of corruption have a strong and positive effect on life insurance development in low-income countries. These effects are weak and marginal for highincome countries. Their study finds the contribution of life insurance market activities decrease as the economy evolves through the higher stages of development. Using insurance as a tax-loaded premium, Soo (1996) developed a dynamic optimization model for individuals maximizing their lifetime utility. This analytical framework provides a window to examine the effect of life insurance on individual and aggregate savings and consumption rates and whether taxing life insurance premium discourages savings, consumption, and wealth (Arena, 2008).

Financial development contributes to economic growth in several ways such as, it allocates resources more efficiently (Wu et al., 2010; Greenwood, Jovanovic, 1990), allows firms to diversify portfolios, raise liquidity and lower risks (Levine, 1991), improve the efficiency of financial intermediation (Rousseau, Xiao, 2007), and increase innovation and entrepreneurship (Greenwood, Smith, 1997). 
Zang and Kim (2007) find substantial evidence that economic growth precedes financial development in a cross-country study. King and Levine (1993) showed that financial depth is a predictor of economic growth and Levine and Zervos (1998) found stock market liquidity predicts economic growth. The connection between banking sector and economic growth is supported by several studies such as (Beck et al., 2000; Levine et al., 2000; Beck, Levine, 2004). However, Demetriades and Law (2006) find financial depth does not affect growth in countries with poor institutions and Rousseau and Wachtel (2000) find that the financial development has no effect on growth in countries with double-digit inflation.

Ward and Zurbruegg (2000) contends that insurance activity contributes to economic growth via risk transfer and indemnification services and financial intermediary services. These services increase productivity, encourage innovation, enhance efficiency, increase investment opportunity, and reduce waste of early monetary realization. Studies by Ward and Zurbruegg (2000), Webb et al. (2002) and Han et al. (2010) have documented the positive effect of insurance market development on economic growth. However, empirical, and theoretical evidences also suggest that the role of insurance may be different across countries. Beenstock et al. (1986) and Browne and Kim (1993) found the demand for life insurance depends on the level of education, age dependency, and other socio-economic factors, which differ across nations. Hence, the relationship between insurance market development and economic growth may differ across countries. Lee (2011) and Arestis et al. (2001) argue that the impact of insurance activities on economic growth may differ among countries due to complementarity effect between insurance sector and stock market instead of substitution effect between insurance and banking sector.

Studies have explored the complementarities between banking sector development, insurance market activity and capital market development and its effect on economic growth (Lee et al., 2013a; Giovannini et al., 2013; Chen et al., 2011; Skipper, 1997; Boyd, Smith, 1998). Over the last two decades, insurance activity has become increasingly important due to risk transfer. Arena (2008) contends, "Given insurers and banks have mutual exposure to common areas, banks sold its credit risks to insurance providers through securitizations and credit portfolios (asset-backed securities and collateralized debt obligations) and derivatives (credit default swaps)" (p. 925). At the same time insurers transfer credit risk to banks by providing liquidity facility and letters of credit (Rule, 2001).

The empirical studies examining the relationship between economic growth and insurance market development use two main econometric approaches - cross-country production function regression and time-series regression. The former examines the determinants of economic growth conditioned on various macroeconomic factors including insurance market development. The later approach examines Granger causality between insurance market development and long-run economic growth. However, there is no conclusive evidence on the direction of causality between insurance market development and economic growth. There is a strand in the literature that insurance market development and economic growth generally follow one of the two hypothesis the demand following hypothesis (DFH) and supply leading hypothesis (SLH). The DFH view as trade and industry expand higher demand for financial services promote additional insurance activity hence, insurance market activity is the outcome of economic growth. Studies supporting demand following hypothesis have published by Beck and Webb (2003), Beenstock et al. (1986), Ching et al. (2010), Guochen and Wei (2012), Han et al. (2010), Hwang and Gao (2003), Kugler and Ofoghi (2005) and Ward and Zurbruegg (2000). The supply leading hypothesis view is insurance market induces economic growth by enhancing savings in the form of financial assets, 
promoting capital formation and economic growth. Studies supporting SLH are (Adams et al., 2009; Alhassan, Fiador, 2014; Boon, 2005; Lee et al., 2013b; Haiss, Sümegi, 2008; Lee, 2011; Vadlamannati, 2008).

Studies in the literature that examine the impact of insurance market development on economic growth (using time-series or cross-section econometric models) generally use a small panel data over a short period of time. Limited number of studies have examined the non-linear relationship between insurance and financial market and economic growth (Arena 2008; Chang, Lee, 2012; Panizza, 2017; Haiss, Sümegi, 2008; Han et al., 2010). However, there is a lack of consistent theoretical work modeling the links among banks, stock markets, insurance market development in a unified framework.

The current study uses cross-section and time-series data and follow supply-leading hypothesis employing Housman-Taylor random effect model to examine the relationship between insurance market development and economic growth in the presence of several variables related to banking, stock market, and insurance activity and their interaction terms (concurrent effect). The major objective is to find if the relationship between insurance activity and economic growth is non-linear. The secondary objective is to find out if the data provide any evidence of complementarities between banking and stock market activities and insurance activity in the growth process. Beck et al. (2000) find exogenous components of banking and insurance measures are positive and strong predictors of economic growth but become weak predictors when the interaction terms are included in the model. This implies banking and insurance market development is complement in the economic growth process.

Recent studies find insurance development can have a positive and/or negative effect on economic growth. Arcand et al. (2015) find large financial sector promotes growth in the presence of a sound institutional environment but can have negative effect on growth for countries with poor institutional infrastructure. Lee et al. (2016) find the relationship between life insurance development and economic growth is negative up to a threshold level due mainly to poor institutional environment. There is also a strand in the literature that supports a non-linear relationship between financial development and economic growth - implying the effect of finance on economic growth is smaller at higher levels of financial development (Masten et al., 2008). Shen and Lee (2006) view the relationship between economic growth and financial development is best described by an inverse U-shape curve. Millo (2016) finds the development of insurance activity is generally slow in the early stages of economic development, then grows more than proportionately and ultimately slows down at the mature stages of development. Chang and Lee (2012) find positive effect economic institutions supporting life insurance market diminishes as the country prospers implying a non-linear (S-curve) relationship between life insurance market and economic growth. Although studies in this line of research recognize the existence of non-linear relationship between insurance market activity and economic growth, none of the studies provide precise functional form capturing the non-linearity, except (Enz, 2000) suggesting a logistic curve.

In the current study, the proxy for insurance market activity measured as insurance penetration (PEN) and density (DEN) entered in the regression as $P E N, P E N^{2}$ and $D E N, D E N^{2}$ to capture the effect of non-linearity. As a general economic theory when a variable in level and square are included in the model, a positive sign on $P E N(D E N)$ and a negative sign on $P E N^{2}\left(D E N^{2}\right)$ imply, remaining all other things constant, a non-linear relationship between economic growth and insurance market development. In other words, faster growth of insurance activity at a later stage of the development process has a negative effect on economic growth. This is one of the major 
contributions for this study because to our knowledge, none of the past studies tested the non-linear relationship between insurance market development and economic growth using cross county panel data and robust econometric model.

\section{The model and methodology}

We follow a modified form of the growth convergence model used by Barro and Sala-i-Martin $(1992,1990)$. To capture the unobserved country effects and endogeneity of some explanatory variables, we use Hausman and Taylor (1981) random effect model. Housman-Taylor (HT) estimator is an instrumental variable estimator that enables the coefficients of time-varying and timeinvariant variables to be estimated. HT model shows that consistent estimate of the coefficients is possible if not all time-varying coefficients are correlated with the unobserved heterogeneity. Generally, if there are more time-varying variables than time-invariant variables, the HT estimator is consistent and efficient. The model assumes there are time-varying and time-invariant independent variables in the model. The model is:

$$
\begin{gathered}
y_{i t}=\beta_{0}+x_{1 i t}^{\prime} \beta_{1}+x_{2 i t}^{\prime} \beta_{2}+z_{1 i}^{\prime} \alpha_{1}+z_{2 i}^{\prime} \alpha_{2}+u_{i}+\varepsilon_{i t}, \\
\mathrm{E}\left[u_{i}\right]=0 ; \quad \operatorname{Var}\left[u_{i}\right]=\sigma_{u}^{2} ; \quad \operatorname{Cov}\left[\varepsilon_{i}+u_{i}\right] 0 ; \\
\operatorname{Var}\left[\varepsilon_{i t}+u_{i}\right]=\sigma^{2}=\sigma_{\varepsilon}^{2}+\sigma_{u}^{2} ; \quad \operatorname{Corr}\left[\varepsilon_{i t}+u_{i}, \varepsilon_{i s} u_{i}\right]=\sigma_{u}^{2} / \sigma^{2} .
\end{gathered}
$$

In the model, $x_{1}$ and $x_{2}$ are time varying, $z_{1}$ and $z_{2}$ are time-invariant variables. The variables $x_{1}$ and $z_{1}$ are uncorrelated with the individual effects $u_{1}$, while $x_{2}$ and $z_{2}$ are correlated with $u_{i}$. Generally, $x_{1 i t}, x_{2 i t}, z_{1 i t}$ and $z_{2 i t}$ are vectors of length $k_{1}, k_{2}, l_{1}$ and $l_{2}$, respectively, subject to identification requirement $k_{1} \geq l_{2}$.

The panel data for this study consist of a maximum of 90 countries covering a period of 1990 2015. The generalized version of the basic model is written as:

$$
\Delta^{\circ}{ }_{P C G D P}=\beta_{0}+\beta^{\prime} P C G D P_{i, t-1}+\gamma^{\prime} C O N T R_{i t}+\delta^{\prime} I N S_{i t}+u_{i}+\varepsilon_{i t},
$$

where $\triangle \% P C G D P_{i t}$ represents growth in per capita GDP, $P C G N I_{i, t-1}$ represents per capita GNI (\$) in the previous year, CONTR represents control variables, INS represents proxies for insurance (life and non-life) market developments and measured as insurance penetration PEN and density $D E N, u$ represents unobserved country specific effects (explained by varying intercepts between countries), and $\varepsilon_{i t}$ represents error term. The subscript $i=1,2, \ldots, N$ represents country and $t=1,2, \ldots, T$ represents time-period. Insurance penetration $(P E N)$ is defined as annual insurance premium volume as percent of GDP and insurance density $(D E N)$ is defined as an annual premium per capita (\$). Unlike most of the studies in the literature, we have estimated separate regression for life and nonlife insurance market development. The variables representing insurance market activity ( $D E N$ and $P E N)$, are expected to be positively correlated with economic growth and the square terms $D E N^{2}$ and $P E N^{2}$ are expected to have negative effect on growth. We define $x_{1}$ variables (exogenous, uncorrelated with $u_{\mathrm{i}}$ ): GNI, GEXP, and INFL; $x_{2}$ variables (endogenous, correlated with $u_{\mathrm{i}}$ ): TRADE, ENROL, PEN, DEN; $z_{1}$ variable (exogenous, uncorrelated with $u_{i}$ ): $O P E N ;$ and $z_{2}$ variable (endogenous, correlated with $u_{\mathrm{i}}$ ): COUNTRY. 
Following Chen et al., (2011), Shen and Lee (2006), Shen et al. (2010), and Arena (2008), we include per capita $G N I_{-1}$ as an independent variable in addition to five macroeconomic variables as control variables (CONTR). Hence, the six control variables are initial income per capita gross national income $(G N I)$, government expenditure as a percent of GDP (GEXP), annual rate of inflation $(I N F)$, openness measured as a ratio of exports and imports to GDP $(O P E N)$, volume of trade as percent of GDP (TRADE), and ratio of total secondary enrollment to population $(E N R O L)$. We expect initial income per capita $(G N I)$, government expenditure $(G E X P)$, and inflation (INFL) are negatively correlated with economic growth and TRADE, OPEN, and ENROL positively correlated with economic growth (Chen et al., 2011, Concha, Taborda, 2014; Arena, 2008; Han et al., 2010; Lee et al., 2016).

\subsection{The extended model}

In this section, we have introduced three different sets of conditions and estimated the interaction of insurance market development on economic growth. Specifically, the set of conditions that we have added are demographic conditions (DEMO) equation (3), economic conditions (ECON) equation (4), and financial conditions (FINA) equation (5) comprising ten additional variables. The extended models are:

$$
\begin{aligned}
& \Delta \% P C G D P_{i t}=\beta_{0}+\beta^{\prime} P C G N I_{i, t-1}+\gamma^{\prime} C O N_{i t}+\delta^{\prime} I N S_{i t}+\eta^{\prime} D E M O_{i t}+u_{i}+\varepsilon_{i t}, \\
& \Delta \% P C G D P_{i t}=\beta_{0}+\beta^{\prime} P C G N I_{i, t-1}+\gamma^{\prime} C O N_{i t}+\delta^{\prime} I N S_{i t}+\psi^{\prime} E C O N_{i t}+u_{i}+\varepsilon_{i t}, \\
& \Delta \% P C G D P_{i t}=\beta_{0}+\beta^{\prime} P C G N I_{i, t-1}+\gamma^{\prime} C O N_{i t}+\delta^{\prime} I N S_{i t}+\varphi^{\prime} F I N A_{i t}+u_{i}+\varepsilon_{i t} .
\end{aligned}
$$

The demographic variables added in equation (3) are young dependency ratio (DEPY) and life expectancy ratio $(L E X P)$ both variables are expected to have a negative impact on growth. In equation (4), the variables added as a proxy for economic conditions are gross fixed capital (FIXCAP), deposit interest rates (DRATE), and real interest rate (RRATE). The interest rate variables are expected to have a negative impact on economic growth which may marginally reduce the positive effect of insurance activity on economic growth. Lastly, equation (5) examines the hypothesis whether the development of insurance market acts as a complement or a substitute for other financial institutions in the country, simultaneously affecting the economic growth. Following Levine and Zervos (1998), Chen et al. (2011), Shen and Lee (2006) and Shen et al. (2010) we use private credit by deposit money as percent of GDP (CREDIT) as a proxy for banking sector development and stock market total value traded as percent of GDP (STOCKTR) as a proxy for stock market development.

\section{Data description and sources}

The variable selection process in this study mainly guided by the principle of tradeoffs between sample size (number of countries) and time-period (number of years) for which the data is currently available. However, in doing so we follow the literature that investigates the relationship between economic growth and financial developments (Lee et al., 2016; Beck, Levine, 2004; Dash et al., 2020). 
Based on pre-selection of the variables used for this study the data/information are collected from various sources. Initially we include 93 countries, 47 high-income, 28 upper-middle income, and 18 lower-middle income countries. Depending on the availability of variables for each country and for the study period, the sample size differs for each model. Appendix A2 provides the list of countries. However due to non-availability of data for some variables/countries for all years under study, several countries are dropped from the final models.

The variables in this study are selected based to its level of significance and expected relationship (negative/positive) with economic growth using HT estimator on equation (2). We begin with the insurance variables ( $P E N$ and $D E N)$ and then added one explanatory variable at a time. The results from life insurance activity are reported in Table 1, columns M-1 through M-6 and the results from nonlife insurance activity are reported in Table 2, columns M-1 through M-6. The upper portion of each table reports results associated with insurance penetration and the lower

Table 1. Testing validity of the variable selection for life insurance activity using HT-model. Dependent variable — annual per capita GDP growth (1995-2015)

\begin{tabular}{|c|c|c|c|c|c|c|}
\hline Variables & M-1 & M-2 & M-3 & M-4 & M-5 & M-6 \\
\hline \multicolumn{7}{|c|}{ Penetration } \\
\hline${ }^{a} G N I_{-1}$ per capita & $-0.853^{* * *}$ & $-0.415^{* * *}$ & $-0.608^{* * *}$ & $-0.811^{* * *}$ & $-0.763 * * *$ & $-1.064 * * *$ \\
\hline${ }^{\mathrm{a}}$ Govt. consumption, GEXP & & $-1.205^{* * *}$ & $-1.183^{* * *}$ & $-1.080^{* * *}$ & $-1.167 * * *$ & $-1.190 * * *$ \\
\hline Inflation, $I N F$ & & & $-0.035 * * *$ & $-0.037 * * *$ & $-0.035 * * *$ & $-0.035 * * *$ \\
\hline a Openness, OPEN & & & & $1.437 * * *$ & $1.253 * * *$ & $1.468 * * *$ \\
\hline Trade, TRADE & & & & & $0.007 * * *$ & $0.007 * * *$ \\
\hline${ }^{\mathrm{b}}$ Tertiary enrollment, ENROL & & & & & & $0.494 * *$ \\
\hline Penetration, $P E N$ & 0.115 & 0.081 & 0.056 & 0.078 & 0.219 & 0.044 \\
\hline${ }^{a}$ Penetration squared, $P E N^{2}$ & 0.012 & 0.037 & 0.043 & 0.034 & 0.025 & 0.034 \\
\hline Constant & $11.484 * * *$ & $12.793 * * *$ & $14.118 * * *$ & $15.738 * * *$ & $15.120 * * *$ & $16.300 * * *$ \\
\hline Chi-squared & 2.14 & 2.15 & 2.16 & 2.00 & 2.15 & 2.27 \\
\hline Countries & 59 & 59 & 59 & 59 & 59 & 59 \\
\hline Observations & 1239 & 1239 & 1239 & 1239 & 1239 & 1239 \\
\hline \multicolumn{7}{|c|}{ Density } \\
\hline${ }^{a} G N I_{-1}$ per capita & $-0.742 * * *$ & -0.061 & -0.170 & -0.483 & -0.432 & $-0.699 * *$ \\
\hline${ }^{\mathrm{a}}$ Govt. consumption, GEXP & & $-1.355 * * *$ & $-1.317 * * *$ & $-1.215 * * *$ & $-1.260 * * *$ & $-1.301 * * *$ \\
\hline Inflation, INF & & & $-0.034 * * *$ & $-0.035 * * *$ & $-0.033 * * *$ & $-0.034 * * *$ \\
\hline apenness, OPEN & & & & $1.557 * * *$ & $1.341 * * *$ & $1.541 * * *$ \\
\hline Trade, TRADE & & & & & $0.007 * * *$ & $0.007 * * *$ \\
\hline${ }^{\mathrm{b}}$ Tertiary enrollment, ENROL & & & & & & $0.475^{* *}$ \\
\hline 'Density, $D E N$ & $0.428 * * *$ & $0.286^{* * *}$ & $0.214^{* *}$ & $0.324 * * *$ & $0.261 * *$ & $0.254^{*}$ \\
\hline${ }^{\mathrm{a} D e n s i t y ~ s q u a r e d,} D E N^{2}$ & $-0.047 * * *$ & $-0.042 * * *$ & $-0.388 * * *$ & $-0.457 * * *$ & $-0.041 * * *$ & $-0.041 * * *$ \\
\hline Constant & $10.199 * * *$ & $9.943 * * *$ & $10.576^{* * *}$ & $12.921 * * *$ & $12.292 * * *$ & $13.202 * * *$ \\
\hline Chi-squared & 2.01 & 2.03 & 2.15 & 2.01 & 2.13 & 2.24 \\
\hline Countries & 59 & 59 & 59 & 59 & 59 & 59 \\
\hline Observations & 1239 & 1239 & 1239 & 1239 & 1239 & 1239 \\
\hline
\end{tabular}

Notes. ${ }^{\mathrm{a}}$ - used as $\log ($ variable $){ }^{\mathrm{b}}$ — used as $\log (1+$ variable); $* * * * *, *$ - significant at 1,5 and $10 \%$ level (resp.). 
Table 2. Testing validity of the variable selection for nonlife insurance activity using HT-model. Dependent variable — annual per capita GDP growth (1995-2015)

\begin{tabular}{|c|c|c|c|c|c|c|}
\hline Variables & M-1 & M-2 & M-3 & M-4 & M-5 & M-6 \\
\hline \multicolumn{7}{|c|}{ Penetration } \\
\hline${ }^{a} G N I_{-1}$ per capita & $-0.785 * * *$ & $-0.486 * * *$ & $-0.595 * * *$ & $-0.899 * * *$ & $-0.086 * * *$ & $-1.017 * * *$ \\
\hline${ }^{\mathrm{a}}$ Govt. consumption, GEXP & & $-1.878 * * *$ & $-1.710^{* * *}$ & $-1.644 * * *$ & $-1.634 * * *$ & $-1.635^{* * *}$ \\
\hline Inflation, $I N F$ & & & $-0.033 * * *$ & $-0.035 * * *$ & $-0.034 * * *$ & $-0.035 * * *$ \\
\hline${ }^{\mathrm{a}}$ Openness, $O P E N$ & & & & $1.620 * * *$ & $1.441 * * *$ & $1.550 * * *$ \\
\hline Trade, $T R A D E$ & & & & & $0.005 * * *$ & $0.006 * * *$ \\
\hline${ }^{\mathrm{b}}$ Tertiary enrollment, ENROL & & & & & & 0.311 \\
\hline 'Penetration, $P E N$ & 0.172 & $0.760 * * *$ & $0.516^{* * *}$ & $0.669 * * *$ & $0.577 * * *$ & $0.528 * *$ \\
\hline${ }^{\text {a }}$ enetration squared, $P E N^{2}$ & $-0.345^{* * *}$ & $-0.620 * * *$ & $-0.563 * * *$ & $-0.515 * * *$ & $-0.497 * * *$ & $-0.478 * * *$ \\
\hline Constant & $11.016^{* * *}$ & $15.395 * * *$ & $15.555^{* * *}$ & $18.089 * * *$ & $17.412 * * *$ & $17.802 * * *$ \\
\hline Chi-squared & 2.02 & 2.00 & 2.83 & 2.21 & 2.00 & 2.01 \\
\hline Countries & 59 & 59 & 59 & 59 & 59 & 59 \\
\hline Observations & 1239 & 1239 & 1239 & 1239 & 1239 & 1239 \\
\hline \multicolumn{7}{|c|}{ Density } \\
\hline${ }^{a} G N I_{-1}$ per capita & $-0.677 * * *$ & -0.568 & -0.435 & $-1.016^{* * *}$ & $-0.970 * * *$ & $-1.083 * * *$ \\
\hline${ }^{\mathrm{a}}$ Govt. consumption, GEXP & & $-1.832 * * *$ & $-1.692 * * *$ & $-1.642 * * *$ & $-1.634 * * *$ & $-1.646 * * *$ \\
\hline Inflation, INF & & & $-0.034 * * *$ & $-0.035 * * *$ & $-0.034 * * *$ & $-0.034 * * *$ \\
\hline${ }^{\mathrm{a} O p e n n e s s,} O P E N$ & & & & $1.593 * * *$ & $1.447 * * *$ & $1.550 * * *$ \\
\hline Trade, TRADE & & & & & $0.005 * * *$ & $0.005 * * *$ \\
\hline${ }^{\mathrm{b}}$ Tertiary enrollment, ENROL & & & & & & $0.341 * * *$ \\
\hline${ }^{\mathrm{a} D e n s i t y, ~} D E N$ & $0.718 * *$ & $1.447 * * *$ & $1.178 * * *$ & $1.327 * * *$ & $1.234 * * *$ & $1.172 * * *$ \\
\hline${ }^{\mathrm{a} D e n s i t y ~ s q u a r e d,} D E N^{2}$ & $-0.083 * * *$ & $-0.139 * * *$ & $-0.128 * * *$ & $-0.125 * * *$ & $-0.118 * * *$ & $-0.115^{* * *}$ \\
\hline Constant & $8.700 * * *$ & $12.793 * * *$ & $11.713 * * *$ & $16.178^{* * *}$ & $15.666^{* * *}$ & $15.815^{* * *}$ \\
\hline Chi-squared & 2.26 & 2.24 & 2.13 & 2.01 & 2.10 & 2.19 \\
\hline Countries & 59 & 59 & 59 & 59 & 59 & 59 \\
\hline Observations & 1239 & 1239 & 1239 & 1239 & 1239 & 1239 \\
\hline
\end{tabular}

Notes. ${ }^{\mathrm{a}}$ - used as $\log ($ variable $) ;{ }^{\mathrm{b}}$ — used as $\log (1+$ variable $) ; * *, * *, *$ — significant at 1,5 and $10 \%$ level (resp.).

part reports results associated with insurance density. The last column of each table (M-6) reports the results from the basic model with all explanatory variables (equation (2)). The results from Table 1 indicate that life insurance penetration variables, $P E N, P E N^{2}$ are not significant but the $D E N$ and $D E N^{2}$ are highly significant and have expected signs. For nonlife insurance activity, Table 2 shows all insurance variables, $P E N, D E N, D E N^{2}$ and $P E N^{2}$ are highly significant and have appropriate signs.

The data on life and non-life insurance market are collected directly from Swiss Reinsurance Company. Information on macroeconomic variables such as, GROW, GNI, GEXP, INFL, FIXCAP, OPEN, TRADE, and ENROL taken from World Development Indicators (WDI, 2016). The data on economic variables (DRATE and RRATE) taken from International Monetary Fund and International Financial Services-World Bank (IMF, IFS-WB). The data on financial variables (CREDIT and STOKTR) taken from Financial Structure and Economic Development 
Database (FSEDD). The data on demographic variables (DEPY and $L E X P$ ) collected from World Development Indicators (WDI). Appendix A0 reports full definitions, measures, sources, and descriptive statistics for the dataset used in this study. Figure 1 reports the scatter plot for life and nonlife penetration (\%) against log of GDP per capita (\%) and Figure 2 reports the scatter plot for life and nonlife log of density (\$) against log of GDP per capita.

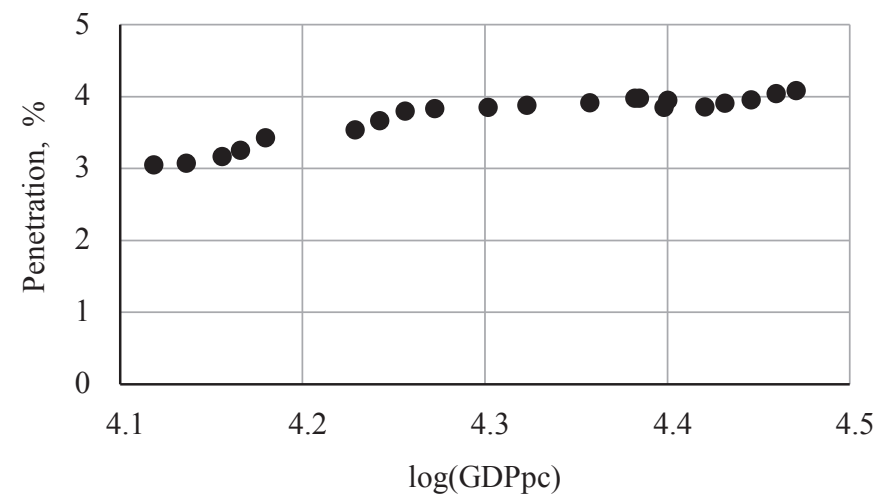

Fig. 1. Scatter plot of insurance penetrations (life and nonlife) and $\log$ (GDP per capita), 1995-2015

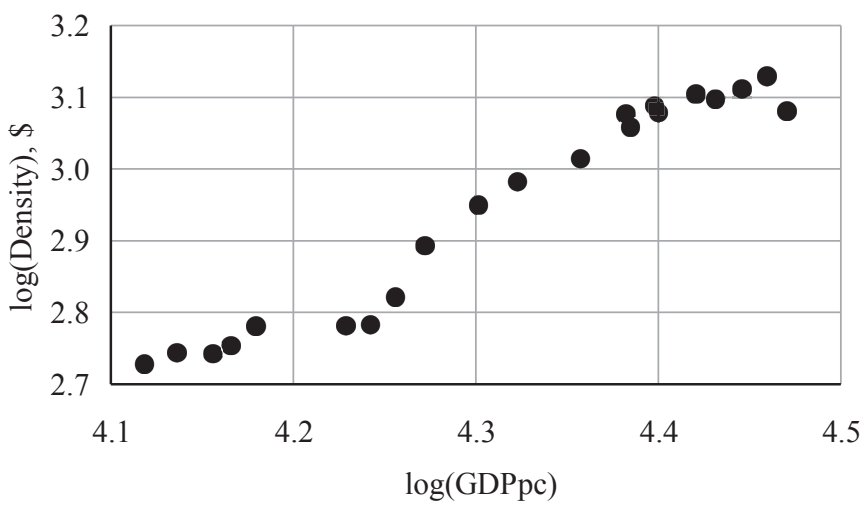

Fig. 2. Scatter plot of insurance density (life and nonlife) and $\log$ (GDP per capita), 1995-2015

Insurance penetration rises with the GDP per capita but the rate of growth of penetration depends on the stages of economic growth. As GDP reaches a certain level, the penetration tends to plateau, which is a typical S-curve phenomenon. It is evident from Figure 1 that although there is an upward trend in penetration over the 26 years of study period, the rate of increase is very slow. Enz (2000) mentions to observe the S-curve phenomenon the time-period need to be very long. The density and penetration measure the relative importance of insurance from two different perspectives. Countries with high GDP tend to spend more on insurance in absolute terms whereas, in relative terms two countries with similar GDP, their spending in insurance could be different (Outreville, 2012). Figure 2 depicts a clear positive relationship between higher density and growth in per capita GDP. 


\section{Empirical results}

The selection of the econometric model for empirical estimation is based on robustness test for the estimation technique. Following Cornwell and Rupert (1988) we use a generalized least square (GLS) regression on the basic model (equation (2)) and compare the results and test statistic with Housman-Taylor (HT) method. Table 3 reports HT and GLS estimates for life insurance (columns 2-5) and nonlife insurance (columns 6-9) activities. GLS model results that relaxes the endogeneity assumption for life insurance (columns 3 and 5) and nonlife insurance (columns 7 and 9) have fewer explanatory variables that are significant compared to HT model.

Table 3. Robustness check Hausman-Taylor (HT) model vs GLS model.

Dependent variable — annual per capita GDP growth (1995-2015)

\begin{tabular}{|c|c|c|c|c|c|c|c|c|}
\hline \multirow{3}{*}{$\begin{array}{l}\text { Description } \\
\text { of variables }\end{array}$} & \multicolumn{4}{|c|}{ Life } & \multicolumn{4}{|c|}{ Nonlife } \\
\hline & HT & GLS & HT & GLS & HT & GLS & HT & GLS \\
\hline & (2) & (3) & (4) & (5) & (6) & (7) & (8) & (9) \\
\hline $\begin{array}{l}{ }^{a} \text { Gross national } \\
\text { income per capita } \\
\text { previous year } \\
G N I_{-1}\end{array}$ & $\begin{array}{c}-1.064 * * * \\
(0.233)\end{array}$ & $\begin{array}{c}-1.755 * * * \\
(0.746)\end{array}$ & $\begin{array}{c}-0.699 * * \\
(0.307)\end{array}$ & $\begin{array}{c}-1.767 * * * \\
(0.745)\end{array}$ & $\begin{array}{c}-1.017 * * * \\
(0.218)\end{array}$ & $\begin{array}{c}-1.777 * * * \\
(0.745)\end{array}$ & $\begin{array}{c}-1.083 * * * \\
(0.366)\end{array}$ & $\begin{array}{c}-1.778 * * * \\
(0.745)\end{array}$ \\
\hline $\begin{array}{l}\text { 'Government } \\
\text { consumption, } \\
G E X P\end{array}$ & $\begin{array}{c}-1.190 * * * \\
(0.340)\end{array}$ & $\begin{array}{l}-0.184 \\
(1.183)\end{array}$ & $\begin{array}{c}-1.301 * * * \\
(0.336)\end{array}$ & $\begin{array}{l}-0.073 \\
(1.185)\end{array}$ & $\begin{array}{c}-1.635 * * * \\
(0.373)\end{array}$ & $\begin{array}{l}-0.116 \\
(1.189)\end{array}$ & $\begin{array}{c}-1.646^{* * *} \\
(0.359)\end{array}$ & $\begin{array}{l}-0.106 \\
(1.186)\end{array}$ \\
\hline Inflation, $I N F$ & & & & $\begin{array}{l}-0.034 \\
(0.028)\end{array}$ & $\begin{array}{c}-0.035 * * * \\
(0.007)\end{array}$ & $\begin{array}{l}-1.036 \\
(0.028)\end{array}$ & $\begin{array}{c}-0.034 * * * \\
(0.007)\end{array}$ & $\begin{array}{l}-0.035 \\
(0.028)\end{array}$ \\
\hline $\begin{array}{l}\text { aOpenness, } \\
O P E N\end{array}$ & & & & $\begin{array}{c}6.371 * * * \\
(2.384)\end{array}$ & $\begin{array}{c}1.550 * * * \\
(0.458)\end{array}$ & $\begin{array}{c}6.604 * * * \\
(2.367)\end{array}$ & $\begin{array}{c}1.550 * * * \\
(0.468)\end{array}$ & $\begin{array}{c}6.569 * * * \\
(2.368)\end{array}$ \\
\hline Trade, $T R A D E$ & & & & $\begin{array}{c}0.008 \\
(0.016)\end{array}$ & $\begin{array}{c}0.006 * * \\
(0.002)\end{array}$ & $\begin{array}{c}0.007 \\
(0.021)\end{array}$ & $\begin{array}{c}0.005^{* * *} * \\
(0.002)\end{array}$ & $\begin{array}{c}0.007 \\
(0.018)\end{array}$ \\
\hline $\begin{array}{l}\text { ' } \text { Tertiary } \\
\text { enrollment, } \\
\text { ENROL }\end{array}$ & $\begin{array}{c}0.494 * * \\
(0.215)\end{array}$ & $\begin{array}{c}-0.035 * * * \\
(0.007)\end{array}$ & $\begin{array}{l}-0.038 \\
(0.028)\end{array}$ & $\begin{array}{c}-0.034 * * * \\
(0.007)\end{array}$ & $\begin{array}{c}0.311 \\
(0.215)\end{array}$ & $\begin{array}{l}-0.133 \\
(1.167)\end{array}$ & $\begin{array}{c}0.341 * * * \\
(0.213)\end{array}$ & $\begin{array}{l}-0.183 \\
(1.039)\end{array}$ \\
\hline $\begin{array}{l}\text { aPenetration, } \\
P E N\end{array}$ & $\begin{array}{c}0.044 \\
(0.090)\end{array}$ & $\begin{array}{c}1.468 * * * \\
(0.459)\end{array}$ & $\begin{array}{c}6.546 * * * \\
(2.376)\end{array}$ & $\begin{array}{c}1.541 * * * \\
(0.483)\end{array}$ & $\begin{array}{l}0.528^{*} \\
(0.267)\end{array}$ & $\begin{array}{c}0.233 \\
(1.288)\end{array}$ & & \\
\hline $\begin{array}{l}{ }^{\text {a}} \text { Penetration } \\
\text { square, } P E N^{2}\end{array}$ & $\begin{array}{c}0.034 \\
(0.033)\end{array}$ & $\begin{array}{c}0.007 * * * \\
(0.002)\end{array}$ & $\begin{array}{c}0.008 \\
(0.026)\end{array}$ & $\begin{array}{c}0.007 * * * \\
(0.002)\end{array}$ & $\begin{array}{c}-0.478 * * * \\
(0.137)\end{array}$ & $\begin{array}{l}-0.487 \\
(0.884)\end{array}$ & & \\
\hline${ }^{\mathrm{a} D e n s i t y,} D E N$ & & & $\begin{array}{l}0.254^{*} \\
(0.145)\end{array}$ & $\begin{array}{c}0.630 \\
(0.694)\end{array}$ & & & $\begin{array}{c}1.172 * * * \\
(0.325)\end{array}$ & $\begin{array}{c}0.718 \\
(1.127)\end{array}$ \\
\hline $\begin{array}{l}{ }^{\mathrm{a} D e n s i t y ~ s q u a r e d,} \\
D E N^{2}\end{array}$ & & & $\begin{array}{c}-0.041 * * * \\
(0.014)\end{array}$ & $\begin{array}{l}-0.094 \\
(0.091)\end{array}$ & & & $\begin{array}{c}-0.115^{* * *} \\
(0.025)\end{array}$ & $\begin{array}{l}-0.087 \\
(0.133)\end{array}$ \\
\hline Constant & $\begin{array}{c}16.300 * * * \\
(1.546)\end{array}$ & $\begin{array}{c}21.158 * * * \\
(5.905)\end{array}$ & $\begin{array}{c}13.202 * * * \\
(1.904)\end{array}$ & $\begin{array}{c}20.749 * * * \\
(5.916)\end{array}$ & $\begin{array}{c}17.802 * * * \\
(2.000)\end{array}$ & $\begin{array}{c}21.076^{* * *} \\
(5.901)\end{array}$ & $\begin{array}{c}15.815^{* * *} \\
(2.998) \\
\end{array}$ & $\begin{array}{c}21.002 * * * \\
(5.908)\end{array}$ \\
\hline Chi-squared & 2.27 & & 2.24 & & 2.01 & & 2.19 & \\
\hline Countries & 59 & 59 & 59 & 59 & 59 & 59 & 59 & 59 \\
\hline Observations & 1239 & 1239 & 1239 & 1239 & 1239 & 1239 & 1239 & 1239 \\
\hline
\end{tabular}

Notes. ${ }^{\mathrm{a}}$ — used as $\log ($ variable $) ;{ }^{\mathrm{b}}$ — used as $\log (1+$ variable $)$; standard errors are in parenthesis; $* * *, * *, *$ — significant at 1, 5 and $10 \%$ level (resp.). 
This suggests that the assumption of no correlation between $u_{\mathrm{i}}$ and $\left(x_{1}, z_{1}\right)$ in GLS model may be incorrect. The null hypothesis that the country specific effects $\left(u_{\mathrm{i}}\right)$ are uncorrelated with the explanatory variables $\left(x_{1}, z_{1}\right)$ is not rejected using $\chi^{2}$-test statistic for all four HT regressions (columns $2,4,6,8)$. Because, with 4 restrictions, two $x$ 's and two $z$ 's, the critical value of $\chi_{4-1}^{2}$ at $99 \%$ level significance is 12.82, which is larger than $\chi^{2}$ values reported in Table 3 (between 2.01 and 2.27). In other words, we cannot reject the null hypothesis that $x_{1}, z_{1}$ are valid instruments and endogeneity does exist in the model.

Since the major interest in this study is to examine the existence of non-linearity in the relationship between insurance activity and economic growth, we report only the estimated coefficients for insurance variables and the test statistics for the basic model in Table 4 . The results from several extended models are not reported in the paper due to page limitations. However, the results are available from the author upon request. The upper half of Table 4 (Part-A) reports regression results for life and nonlife insurance models using penetration variable $\left(P E N, P E N^{2}\right)$ and the lower half (Part-B) reports regression results using density variable $\left(D E N, D E N^{2}\right)$. Columns 2 and 3 reports the basic model, columns 4 and 5 - the demographic model, columns 6 and 7 - economic model, and columns 8 and 9 - for financial model.

It is evident from Table 4 that the coefficients on $P E N$ and $P E N^{2}$ for all models generally have the expected signs but have weak association with economic growth. All coefficients on $D E N$

Table 4. Effect of insurance activity on economic growth.

Dependent variable — annual per capita GDP growth (1995-2015)

\begin{tabular}{|c|c|c|c|c|c|c|c|c|}
\hline \multirow[t]{2}{*}{$\begin{array}{l}\text { Description } \\
\text { of variables }\end{array}$} & \multicolumn{2}{|c|}{$\begin{array}{l}\text { Basic model } \\
\text { (Appendix A1) }\end{array}$} & \multicolumn{2}{|c|}{ Demographic } & \multicolumn{2}{|c|}{ Economic } & \multicolumn{2}{|c|}{ Financial } \\
\hline & Life & Nonlife & Life & Nonlife & Life & Nonlife & Life & Nonlife \\
\hline \multicolumn{9}{|c|}{ Part-A } \\
\hline apenetration, PEN & $\begin{array}{c}0.044 \\
(0.043)\end{array}$ & $\begin{array}{l}0.528 * * \\
(0.267)\end{array}$ & $\begin{array}{l}-0.008 \\
(0.068)\end{array}$ & $\begin{array}{c}0.035 \\
(0.212)\end{array}$ & $\begin{array}{l}-0.105 \\
(0.126)\end{array}$ & $\begin{array}{c}0.005 \\
(0.548)\end{array}$ & $\begin{array}{l}0.210^{*} \\
(0.124)\end{array}$ & $\begin{array}{l}-0.031 \\
(0.280)\end{array}$ \\
\hline $\begin{array}{l}\text { apenetration } \\
\text { squared, } P E N^{2}\end{array}$ & $\begin{array}{c}0.034 \\
(0.034)\end{array}$ & $\begin{array}{c}-0.478^{* *} \\
(0.137)\end{array}$ & $\begin{array}{l}0.049^{*} \\
(0.031)\end{array}$ & $\begin{array}{c}-0.340 * * * \\
(0.120)\end{array}$ & $\begin{array}{l}-0.056 \\
(0.180)\end{array}$ & $\begin{array}{l}-0.305^{*} \\
(0.180)\end{array}$ & $\begin{array}{l}-0.070 \\
(0.061)\end{array}$ & $\begin{array}{l}-0.155 \\
(0.139)\end{array}$ \\
\hline Autocorrelation & 0.037 & 0.037 & 0.029 & 0.028 & 0.036 & 0.037 & 0.041 & 0.041 \\
\hline Rho & 0.981 & 0.981 & 0.985 & 0.985 & 0.981 & 0.981 & 0.979 & 0.979 \\
\hline Chi-squared & 2.27 & 2.01 & 5.13 & 7.22 & 3.02 & 2.85 & 2.00 & 2.29 \\
\hline \multicolumn{9}{|c|}{ Part-B } \\
\hline${ }^{\mathrm{a} D}$ Density, $D E N$ & $\begin{array}{l}0.254^{*} \\
(0.145)\end{array}$ & $\begin{array}{c}1.172 * * * \\
(0.325)\end{array}$ & $\begin{array}{c}0.041 \\
(0.112)\end{array}$ & $\begin{array}{c}0.629 * * * \\
(0.237)\end{array}$ & $\begin{array}{l}0.245^{*} \\
(0.455)\end{array}$ & $\begin{array}{l}0.899 * * \\
(0.455)\end{array}$ & $\begin{array}{c}1.011^{* * *} \\
(0.201)\end{array}$ & $\begin{array}{c}0.789^{* * *} \\
(0.295)\end{array}$ \\
\hline $\begin{array}{l}\text { a Density squared, } \\
D E N^{2}\end{array}$ & $\begin{array}{c}-0.041 * * * \\
(0.014)\end{array}$ & $\begin{array}{c}-0.115^{* * *} \\
(0.025)\end{array}$ & $\begin{array}{l}-0.015 \\
(0.012)\end{array}$ & $\begin{array}{c}-0.084 * * * \\
(0.020)\end{array}$ & $\begin{array}{c}-0.040 * * * \\
(0.027)\end{array}$ & $\begin{array}{c}-0.108 * * * \\
(0.027)\end{array}$ & $\begin{array}{c}-0.088^{* * *} \\
(0.019)\end{array}$ & $\begin{array}{c}-0.074 * * * \\
(0.024)\end{array}$ \\
\hline Autocorrelation & 0.037 & 0.036 & 0.028 & 0.027 & 0.036 & 0.037 & 0.040 & 0.041 \\
\hline Rho & 0.981 & 0.981 & 0.985 & 0.986 & 0.981 & 0.981 & 0.979 & 0.979 \\
\hline Chi-squared & 2.24 & 2.19 & 5.70 & 6.91 & 2.77 & 2.46 & 2.09 & 2.40 \\
\hline Countries & 59 & 59 & 78 & 78 & 46 & 46 & 53 & 53 \\
\hline Observations & 1239 & 1239 & 1638 & 1638 & 966 & 966 & 1113 & 1113 \\
\hline
\end{tabular}

Notes. ${ }^{\mathrm{a}}$ — used as $\log$ (variable); ${ }^{\mathrm{b}}$ — used as $\log (1+$ variable $) ;$ standard errors are in parenthesis; $* * *, * *, *$ _ significant at 1,5 and $10 \%$ level (resp.). 
and $D E N^{2}$ are highly significant and have correct signs. For example, positive and significant coefficients on $P E N$ and $D E N$ suggest overall insurance activities (life and nonlife) are positively correlated to economic growth, while negative and significant coefficient in $P E N^{2}$ and $D E N^{2}$ imply at higher stages of economic development increased insurance activities have a negative effect on economic growth. In other words, there is a non-linear relationship between insurance activities and economic growth.

Appendix A1 reports the results from the basic model equation (2) using Hausman-Taylor estimation method. Columns 2 and 3 report result for life insurance market and columns 4 and 5 report results for nonlife insurance market. It is evident from Appendix A1 that the life insurance penetration $\left(P E N\right.$ and $\left.P E N^{2}\right)$ and density variables $\left(D E N\right.$ and $\left.D E N^{2}\right)$ are mostly significant and have correct signs. Strong and positive sign on the coefficient of $D E N$ implies 1 percent increase in $D E N$ increases economic growth by 0.025 percent. The strong and negative sign on $D E N^{2}$ implies the impact of life insurance density on growth is non-linear. In other words, a strong second-order polynomial relationship exists between economic growth and life insurance market development. For nonlife insurance, highly significant and positive $P E N$ and $D E N$ imply insurance development has positive impact on economic growth. This suggests for nonlife insurance 1 percent increase in $P E N$ increases economic growth by 0.002 percent. Strong and negative coefficient on the $P E N^{2}$ and $D E N^{2}$ show a non-linear relationship between nonlife insurance development and economic growth. Meaning higher level of insurance activity reduces economic growth.

The control variables in Appendix A1 such as, GNI, GEXP and INFL are highly significant and negative implying increase in any of these variables reduces economic growth, which is consistent with the results obtained by Han et al. (2010) and Chen et al. (2011). Negative sign on initial income per capita (GNI) implies higher the historical income growth slower is the economic growth, which is consistent with S-curve hypothesis (Enz, 2000). Other control variables such as, OPEN, TRADE and ENROL are also highly significant and have positive effect on economic growth. Positive and mostly significant effect of education (ENROL) for life and nonlife insurance on economic growth implying higher level of education is associated with higher economic growth. The results are consistent with (Han et al., 2010; Arena, 2008; Chen et al., 2011; U1 Din et al., 2017; Concha, Taborda, 2014).

The results from the extended models (equations (3)-(5)) not reported in the paper, examine the effects of development of life and nonlife insurance activities on economic growth, subject to marginal influence by other conditional variables. In other words, the extended models examine the marginal impact of each conditional variable on economic growth while indirectly influencing the relationship between insurance market development and economic growth.

\subsection{Demographic conditions}

The impact of life and nonlife insurance development on economic growth in the presence of two demographic variables is examined using equation (3). The variables used are young dependency ratio $(D E P Y)$, measured as share between the population aged $65+$ and those aged 15-64 and the life expectancy ( $L E X P)$ (results not reported in the paper). Both variables appear strong and significant for life insurance and nonlife insurance development. However, negative signs suggest increase DEPY and LEXP reduce economic growth. Beenstock et al. (1986), Truett and Truett (1990), and Browne and Kim (1993) find positive correlation between life insurance 
penetration and young dependency ratio and Beck and Webb (2003) find young dependency ratio has no robust relationship with life insurance activities. Further, Chen et al. (2011) find young dependency ratio is significant and negatively correlated with economic growth for life insurance activity. The authors argue dependency ratio can have different impact across different country and across different business lines. Overall, the results are consistent with the literature. Chen et al. (2011) and Chang and Lee (2012) find the effect of demographic variables on economic growth becomes negative when interaction terms (density*DEPY; penetration*DEPY) are included in the model. We do not use any interaction term for demographic variables in the model.

\subsection{Economic conditions}

For economic condition, we introduce three proxy variables viz., deposit interest rate (DRATE), real interest rate (RRATE), and fixed capital (FCAP) (results not reported in the paper). For life insurance market DRATE is significant and negative and FCAP is significant and positive. This implies increase in DRATE reduces economic growth. We argue negative DRATE probably affecting insurance penetration marginally as a result, $P E N$ and $P E N^{2}$ are insignificant. The variable $R R A T E$ has correct sign but insignificant. For nonlife insurance DRATE and FCAP are highly significant and have the correct signs but RRATE is insignificant. However, variables TRADE and OPEN are generally insignificant for both life and nonlife market.

\subsection{Financial conditions}

Two proxy variables we use for financial conditions in equation (5) private credit by deposit money bank as percent of GDP (CREDIT) and stock market total value traded as percent of GDP $(S T O K T R)$. In this regression, we introduce the interaction terms for variables CREDIT and STOKTR, and insurance market activity (PEN and DEN). To examine the concurrent relationship between insurance development, banking activity, and stock market activities in economic growth process, we estimate the basic model (equation (2)) including all financial condition variables without the interaction terms. Insurance variables for both life and nonlife have strong and positive effect on economic growth. Consistent with the literature stock trading has positive and significant and private credit has negative and significant effect on economic growth. Further, highly significant, and negative $P E N^{2}$ and $D E N^{2}$ for both life and nonlife insurance activity imply the effect of insurance development on economic growth is non-linear.

The interaction terms for STOKTR and CREDIT are negative and significant. This implies while magnitude of the positive effect of insurance activity on economic growth alleviate by stock trading, it reduces by banking activities. We find stock market and life insurance market development significantly positively related to economic growth and banking development has significantly negative effect on economic growth. Further, the negative and significant interaction terms imply banking sector and stock market indicators have substitute effect on life insurance development in the economic growth process. There are studies in the literature that investigate whether banking sector and stock market activities are complement or substitute, while contributing positively to economic growth. So far, the results in the literature are mixed. For example, Arena (2008) found complementarity between insurance market development and banking sector and stock market 
indicators, and each contribute positively to economic growth. Chen et al. (2011) find substitute effect between life insurance and stock market indicators in economic growth process.

When we use the interaction terms in the model, we find all interaction terms are negative and highly significant implying banking and stock market activity (CREDIT and STOKTR) hinder the positive effect of nonlife insurance activity on economic growth. Hence, banking and stock market development and nonlife insurance market activity act as substitute in the economic growth process. Haiss and Sümegi (2008) argue that an expanding insurance sector reduces the positive effect of banking and stock market on economic growth.

Finally, as an extension of the model, we investigate the effect of insurance development on economic growth for countries grouped into two income levels. We assess the causal effect of insurance market activity on economic growth (basic model, equation (2)) for 40 High-income countries (developed) and 38 Middle-Low income countries (developing) (results not reported in the paper). For High-income countries both life and nonlife insurance market penetration and density variables and its square terms have expected signs with mixed significance. For Middle-Low income countries life insurance penetration is significant but does not satisfy the non-linearity hypothesis. The same is true for density. For nonlife insurance, only the square terms $\left(P E N^{2}, D E N^{2}\right)$ have correct signs and are significant which suggests non-linearity. We argue when we group the countries based on income levels evidences generally support the non-linear relationship between insurance activity and economic growth. Further, we find that both life and nonlife insurance activity in High-income countries mainly drive the economic growth. Nonlife insurance activity in Middle-Low income countries is not significant. Arena (2008) uses panel data from 55 countries for 28 years and finds life and nonlife insurance market development have bigger impact on economic growth for low and middle-income countries compared with high-income countries. Haiss and Sümegi (2008) find life insurance has a positive relationship with economic growth in Highincome countries and nonlife insurance has a positive relationship with economic growth in Lowincome countries. Han et al. (2010) find life and nonlife insurance businesses play much more important role in developing countries compared with developed countries.

\section{Summary and conclusions}

This paper investigates the relationship between insurance market development and economic growth using cross-country panel data from 90 countries over the period 1995-2015. Using life and nonlife insurance density and penetration separately as proxy for insurance activity, we investigate the effect of demographic, economic, financial conditions, including grouping countries based on income levels and examined insurance-growth nexus. Model selection test suggests Hausman-Taylor model is superior to GLS model used in this study and best represents the data. We find evidence for strong and positive effect of life and nonlife insurance development on economic growth. The positive effect of insurance development on economic growth is influenced by the negative impact of deposit interest rate, real interest rate, private-credit, life expectancy, and young dependency ratio. All macroeconomic variables have expected signs and are statistically significant. This study finds both banking and stock market developments are substitute for insurance market development in the economic growth process. Consistent with the past studies, we find for High-income countries both life and nonlife insurance penetration mainly drive the economic growth and for Middle-Low income countries, only life insurance penetration drive 
the economic growth. One of the major findings from this study is that we find consistent evidence for non-linear relationship between insurance development and economic growth. The nonlinear relationship is observed when we group the countries based on income levels.

This study offers several useful insights for the policymakers and researchers. Although insurance market development enhances economic growth but well-developed financial market infrastructure, i.e., high level of banking and stock market activities may reduce the positive impact of insurance on economic growth. The non-linearity between insurance development and economic growth implies at initial stages of economic growth higher level of insurance activity leads to higher economic growth but once the country reaches maturity, higher insurance activity may lead to lower economic growth. Hence, policymakers need to find some complementarity between banking sector, stock market activity, and insurance market development through financial innovations. For sustained economic growth, while promoting insurance activities government should make effort to reduce real interest rate, deposit interest rate, and stock market activities.

Further, policymakers also need to recognize the demographic structure and the income levels of the population because as evident from the study, higher dependency ratio and life expectancy may lower the positive effect of insurance activity on economic growth. A study by United Nations (2017) reports a declining fertility rates and increasing life expectancy shrinking the workforce and higher dependency ratio. In a few decades, Population in China and Thailand will age faster than Europe and North America. For example, by 2055, the age dependency ratio in China expected to reach 50 percent posing a significant challenge to society (Swiss Re, 2019). This phenomenon will gear up higher government spending on healthcare and pensions, which will crowd out public spending on infrastructure and education. Hence, public policy raising retirement age would have a positive impact on workers' saving and pension contributions mobilizing resources for financial activities including insurance spending. This will create capital formation and further economic growth.

Acknowledgments. The author is thankful for the valuable comments and suggestions by Prof. Subal Kumbhakar at Binghamton University on an earlier version of the paper. The author is grateful to the unknown reviewers of this journal for their helpful comments/suggestions which have improved the methodology and presentation of this paper extensively.

\section{References}

Acemoglu D. (2007). An introduction to modern economic growth. Department of Economics, MIT, Draft of the Book Manuscript. Version. 2.2: October.

Adams M., Andersson J., Andersson L.-F., Lindmark M. (2009). Commercial banking, insurance, and economic growth in Sweden between 1830 and 1998. Accounting, Business \& Financial History, 19 (1), 21-38.

Alhassan A. L., Fiador V. (2014). Insurance-growth nexus in Ghana: An autoregressive distributed lag bounds cointegration approach. Review of Development Finance, 4 (2), 83-96.

Ang J. B. (2008). A survey of recent developments in the literature of finance and growth. Journal of Economic Surveys, 22 (3), 536-576.

Arcand J. L., Berkes E., Panizza U. (2015). Too much finance? Journal of Economic Growth, 20 (2), 105-148.

Arena M. (2008). Does insurance market activity promote economic growth? A cross-country study for industrialized and developing countries. Journal of Risk and Insurance, 75 (4), 921-946.

Arestis P., Demetriades P. O., Luintel K. B. (2001). Financial development and economic growth: The role of stock markets. Journal of Money, Credit and Banking, 33 (1), 16-41. 
Barro R. J., Sala-i-Martin X. (1990). Economic growth and convergence across the United States. NBER Working Paper 3419. Cambridge, MA.

Barro R. J., Sala-i-Martin X. (1992). Convergence. Journal of Political Economy, 100 (2), 223-251.

Beck T., Levine R. (2004). Stock markets, banks, and growth: Panel evidence. Journal of Banking \& Finance, 28 (3), 423-442.

Beck T., Levine R., Loayza N. (2000). Finance and the sources of growth. Journal of Financial Economics, 58 (1-2), 261-300.

Beck T., Webb I. (2003). Economic, demographic, and institutional determinants of life insurance consumption across countries. The World Bank Economic Review, 17 (1), 51-88.

Beenstock M., Dickinson G., Khajuria S. (1986). The determination of life premiums: An international cross-section analysis 1970-1981. Insurance: Mathematics and Economics, 5 (4), 261-270.

Boon T. K. (2005). Do commercial banks, stock market and insurance market promote economic growth? An analysis of the Singapore economy. Working Paper. Nanyang Technological University, Singapore. http://www.ceistorvergata.it/conferenze\&convegni/banking\&finance/XII_conference/11DICEMBRE/Boon.pdf.

Boyd J. H., Smith B. D. (1998). The evolution of debt and equity markets in economic development. Economic Theory, 12 (3), 519-560.

Browne M. J., Kim K. (1993). An international analysis of life insurance demand. The Journal of Risk and Insurance, 60 (4), 616-634.

Carter R. L., Dickinson G. M. (1992). Obstacle to liberalization of trade in insurance. London: Harvester Wheatsheaf.

Catalan M., Impavido G., Musalem A. R. (2000). Contractual savings or stock markets development: Which leads? World Bank Policy Research Paper No. 2421.

Chang C.-H., Lee C.-C. (2012). Non-linearity between life insurance and economic development: A revisited approach. The Geneva Risk and Insurance Review, 37 (2), 223-257.

Chen P.-F., Lee C.-C., Lee C.-F. (2011). How does the development of the life insurance market affect economic growth? Some international evidence. Journal of International Development, 24 (7), 865-893.

Ching K. S., Kogid M., Furuoka F. (2010). Causal relation between life insurance funds and economic growth evidence from Malaysia. Asian Economic Bulletin, 27 (2), 185-199.

Concha Á., Taborda R. (2014). Insurance use and economic growth in Latin America. Some panel data evidence. Lecturas de Economía, (81), 31-55.

Cornwell C., Rupert P. (1988). Efficient estimation with panel data: An empirical comparison of instrumental variables estimators. Journal of Applied Econometrics, 3 (2), 149-155.

Dash S., Pradhan R. P., Maradana R. P., Gaurav K., Jayakumar M. (2020). Impact of banking sector development on insurance market-growth nexus: The study of Eurozone countries. Empirica, 47 (2), 205-243.

Demetriades P., Law S. H. (2006). Finance, institutions, and economic development. International Journal of Finance \& Economics, 11 (3), 245-260.

Enz R. (2000). The S-curve relation between per-capita income and insurance penetration. Geneva Papers on Risk and Insurance - Issues and Practice, 25 (3), 396-406.

Freytag A., Fricke S. (2017). Sectoral linkages of financial services as channels of economic development an input-output analysis of the Nigerian and Kenyan economies. Review of Development Finance, 7 (1), 36-44.

Giovannini A., Iacopetta M., Minetti R. (2013). Financial markets, banks, and growth: Disentangling the links. Revue de l'OFCE, 131 (5), 105-147.

Goldsmith R. W. (1969). Financial structure and development. Yale University Press. New Haven. 
Grace M. F., Rebello M. J. (1993). Financing and the demand for corporate insurance. The Geneva Papers on Risk and Insurance Theory, 18 (2), 147-171.

Greenwood J., Jovanovic B. (1990). Financial development, growth, and the distribution of income. Journal of Political Economy, 98 (5, Part 1), 1076-1107.

Greenwood J., Smith B. D. (1997). Financial markets in development, and the development of financial markets. Journal of Economic Dynamics and Control, 21 (1), 145-181.

Guochen P., Wei S. C. (2012). The relationship between insurance development and economic growth: A cross-region study for China. Paper presented at the 2012 China International Conference on Insurance and Risk Management. Qingdao, July 18-21.

Haiss P., Sümegi K. (2008). The relationship between insurance and economic growth in Europe: A theoretical and empirical analysis. Empirica, 35 (4), 405-431.

Han L., Li D., Moshirian F., Tian Y. (2010). Insurance development and economic growth. The Geneva Papers on Risk and Insurance - Issues and Practice, 35 (2), 183-199.

Hausman J., Taylor W. (1981). Panel data and unobservable individual effects. Journal of Econometrics, $16(1), 155$.

Hwang T., Gao S. (2003). The determinants of the demand for life insurance in an emerging economy the case of China. Managerial Finance, 29 (5/6), 82-96.

King R. G., Levine R. (1993). Finance and growth: Schumpeter might be right. The Quarterly Journal of Economics, 108 (3), 717-737.

Kugler M., Ofoghi R. (2005). Does insurance promote economic growth? Evidence form UK. In: Money Macro and Finance Research Group/MMF Research Group Conference, Sep.1-3, University of Crete, Rethymno, Greece.

Lee C.-C. (2011). Does insurance matter for growth: Empirical evidence from OECD countries. The B. E. Journal of Macroeconomics, 11 (1), 1-28.

Lee C.-C., Chang C.-H., Arouri M., Lee C.-C. (2016). Economic growth and insurance development: The role of institutional environments. Economic Modelling, 59, 361-369.

Lee C.-C., Huang W.-L., Yin C.-H. (2013a). The dynamic interactions among the stock, bond, and insurance markets. The North American Journal of Economics and Finance, 26 (3), 28-52.

Lee C.-C., Lee C.-C., Chiu Y.-B. (2013b). The link between life insurance activities and economic growth: Some new evidence. Journal of International Money and Finance, 32 (3), 405-427.

Levine R. (1991). Stock markets, growth, and tax policy. The Journal of Finance, 46 (4), 1445-1465.

Levine R., Zervos S. (1998). Stock market, banks, and economic growth. American Economic Review, $88,537-558$.

Levine R., Loayza N., Beck T. (2000). Financial intermediation and growth: Causality and causes. Journal of Monetary Economics, 46 (1), 31-77.

Lu C., Yanagihara M. (2013). Life insurance, human capital accumulation and economic growth. Australian Economic Papers, 52 (1), 52-60.

Masten A. B., Coricelli F., Masten I. (2008). Non-linear growth effects of financial development: Does financial integration matter? Journal of International Money and Finance, 27 (2), 295-313.

Millo G. (2016). The S-curve and reality. The Geneva Papers on Risk and Insurance - Issues and Practice, 41 (4), 608-625.

Outreville J. F. (2012). The relationship between insurance and economic development: 85 empirical papers for a review of the literature. Risk Management and Insurance Review, 16 (1), 71-122. 
Panizza U. (2017). Nonlinearities in the relationship between finance and growth. Comparative Economic Studies, 60 (1), 44-53.

Rousseau P. L., Wachtel P. (2000). Equity markets and growth: Cross-country evidence on timing and outcomes, 1980-1995. Journal of Banking and Finance, 24 (12), 1933-1957.

Rousseau P. L., Xiao S. (2007). Banks, stock markets, and China's 'great leap forward'. Emerging Markets Review, 8 (3), 206-217.

Rule D. (2001). Risk transfer between banks, insurance companies and capital markets. Financial Stability Review, 37, 613-622.

Schumpeter J. A. (1934). The theory of economic development: An inquiry into profits, capital, credit, interest, and the business cycle. Harvard University Press.

Skipper H. Jr. (1997). Foreign insurers in emerging markets: Issues and concerns. Occasional Paper 97-2. Center for Risk Management and Insurance.

Shen C.-H., Lee C.-C. (2006). Same financial development yet different economic growth — why? Journal of Money, Credit, and Banking, 38 (7), 1907-1944.

Shen C.-H., Lee C.-C., Lee C.-C. (2010). What makes international capital flows promote economic growth? An international cross-country analysis. Scottish Journal of Political Economy, 57 (5), 515-546.

Soo H. H. (1996). Life insurance and economic growth: Theoretical and empirical investigation. PhD Dissertation, ETD collection for University of Nebraska-Lincoln. AAI9712527. https://digitalcommons.unl.edu/dissertations/AAI9712527.

Swiss Re. (2018). World insurance in 2017: Solid but mature life markets weigh on growth. Sigma 3/2018. https://www.swissre.com/institute/research/sigma-research/sigma-2018-03.html.

Truett D. B., Truett L. J. (1990). The demand for life insurance in Mexico and the United States: A comparative study. The Journal of Risk and Insurance, 57 (2), 321-328.

U1 Din S. M., Abu-Bakar A., Regupathi A. (2017). Does insurance promote economic growth: A comparative study of developed and emerging/developing economies? Cogent Economics and Finance, $5(1), 2-12$.

United Nations (2017). World Population Prospects: The 2017 Revision. https://www.un.org/develop$\mathrm{ment} / \mathrm{desa} /$ publications/world-population-prospects-the-2017-revision.html.

Vadlamannati K. C. (2008). Do insurance sector growth and reforms affect economic development? Empirical evidence from India. Margin: The Journal of Applied Economic Research, 2 (1), 43-86.

Ward D., Zurbruegg R. (2000). Does insurance promote economic growth? Evidence from OECD countries. The Journal of Risk and Insurance, 67 (4), 489-506.

Webb I., Grace M., Skipper H. (2002). The effect of banking and insurance on growth of capital and output. Centre for Risk Management, and Insurance Working Paper 02-1. Georgia State University, Atlanta.

WDI (2016). World development indicators. The World Bank. http://datatopics.worldbank.org/ world-development-indicators/.

Wu J.-L., Hou H., Cheng S.-Y. (2010). The dynamic impacts of financial institutions on economic growth: Evidence from the European Union. Journal of Macroeconomics, 32 (3), 879-891.

Zang H., Kim Y. C. (2007). Does financial development precede growth? Robinson and Lucas might be right. Applied Economics Letters, 14 (1), 15-19.

Zou H., Adams M. B. (2006). The corporate purchase of property insurance: Chinese evidence. Journal of Financial Intermediation, 15 (2), 165-196.

Received 14.05.2020; accepted 30.09.2020. 


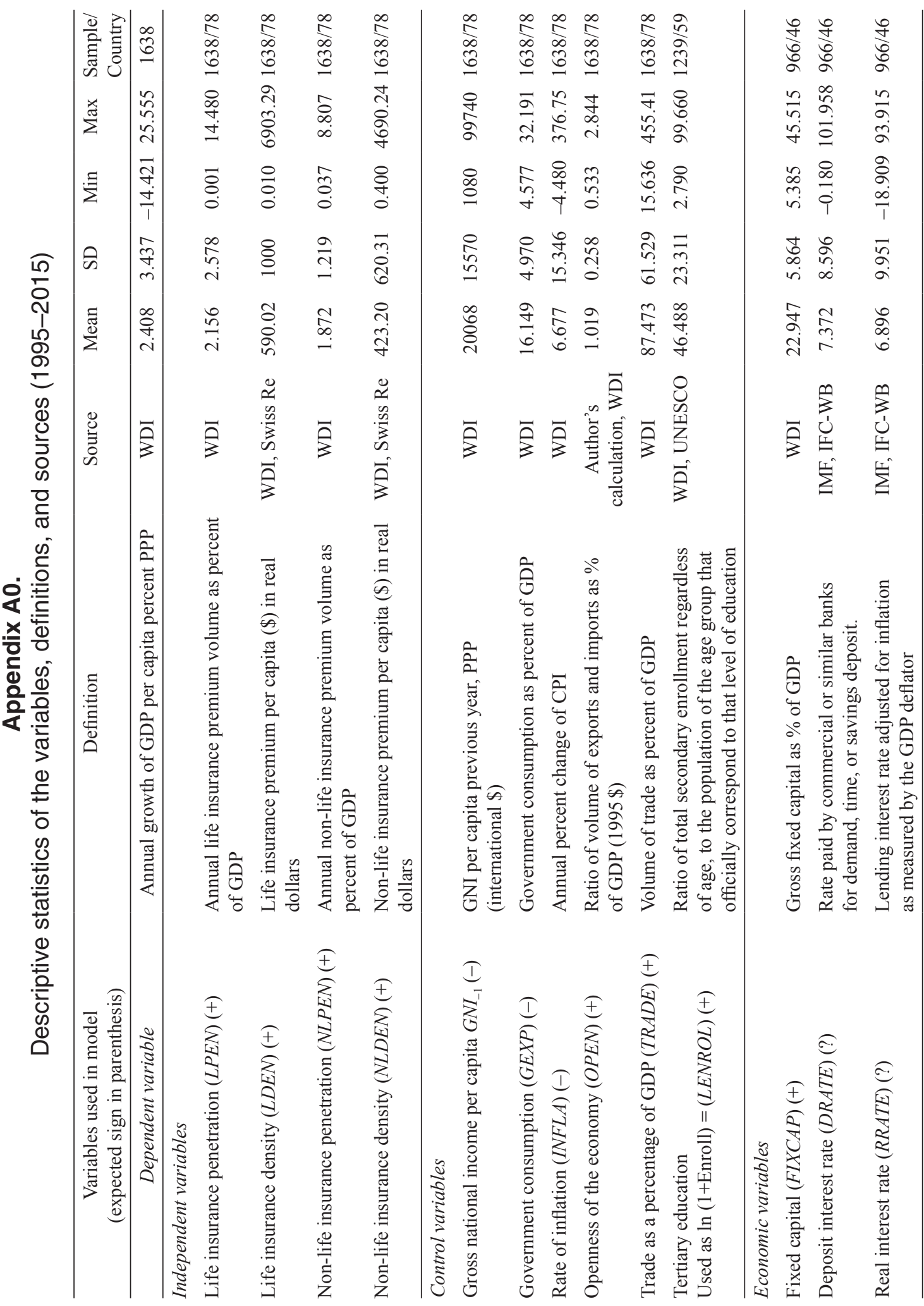




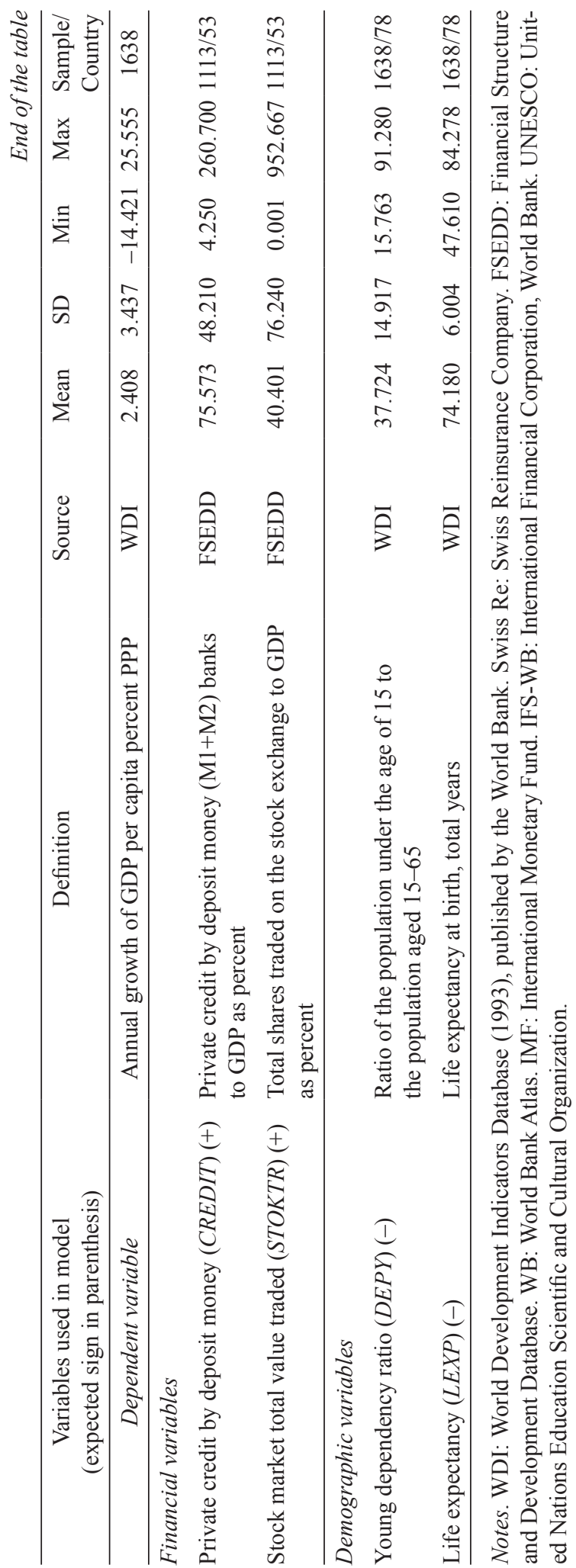


Appendix A1. Basic model: Hausman-Taylor random effect model. Dependent variable — annual per capita GDP growth (1995-2015)

\begin{tabular}{|c|c|c|c|c|}
\hline \multirow[t]{2}{*}{ Description of variables } & \multicolumn{2}{|c|}{ Life } & \multicolumn{2}{|c|}{ Non-life } \\
\hline & Coefficients & Coefficients & Coefficients & Coefficients \\
\hline $\begin{array}{l}\text { a Gross national income per capita } \\
\text { previous year, } G N I_{-1}\end{array}$ & $\begin{array}{c}-1.064 * * * \\
(0.233)\end{array}$ & $\begin{array}{c}-0.699 * * \\
(0.307)\end{array}$ & $\begin{array}{c}-1.017 * * * \\
(0.218)\end{array}$ & $\begin{array}{c}-1.083 * * * \\
(0.366)\end{array}$ \\
\hline a'Government consumption, GEXP & $\begin{array}{c}-1.190 * * * \\
(0.340)\end{array}$ & $\begin{array}{c}-1.301 * * * \\
(0.336)\end{array}$ & $\begin{array}{c}-1.635 * * * \\
(0.372)\end{array}$ & $\begin{array}{c}-1.646^{* * *} \\
(0.359)\end{array}$ \\
\hline Inflation, $I N F$ & $\begin{array}{c}-0.035 * * * \\
(0.007)\end{array}$ & $\begin{array}{c}-0.034 * * * \\
(0.007)\end{array}$ & $\begin{array}{c}-0.035 * * * \\
(0.007)\end{array}$ & $\begin{array}{c}-0.034 * * * \\
(0.007)\end{array}$ \\
\hline apenness, $O P E N$ & $\begin{array}{l}1.468 * * * \\
(0.459)\end{array}$ & $\begin{array}{l}1.541 * * * \\
(0.483)\end{array}$ & $\begin{array}{l}1.550 * * * \\
(0.458)\end{array}$ & $\begin{array}{l}1.550 * * * \\
(0.468)\end{array}$ \\
\hline Trade, $T R A D E$ & $\begin{array}{l}0.007 * * * \\
(0.002)\end{array}$ & $\begin{array}{c}0.007 * * * \\
(0.002)\end{array}$ & $\begin{array}{l}0.006 * * \\
(0.002)\end{array}$ & $\begin{array}{c}0.005 * * * \\
(0.002)\end{array}$ \\
\hline${ }^{\mathrm{b}}$ Tertiary enrollment, ENROL & $\begin{array}{l}0.494 * * \\
(0.215)\end{array}$ & $\begin{array}{c}0.475 * * \\
(0.212)\end{array}$ & $\begin{array}{c}0.311 \\
(0.215)\end{array}$ & $\begin{array}{l}0.341 * * * \\
(0.213)\end{array}$ \\
\hline${ }^{\text {a}}$ Penetration, $P E N$ & $\begin{array}{c}0.044 \\
(0.090)\end{array}$ & & $\begin{array}{l}0.528 * * \\
(0.267)\end{array}$ & \\
\hline${ }^{\text {a}}$ Penetration squared, $P E N^{2}$ & $\begin{array}{c}0.034 \\
(0.033)\end{array}$ & & $\begin{array}{c}-0.478 * * * \\
(0.137)\end{array}$ & \\
\hline${ }^{\mathrm{a} D e n s i t y,} D E N$ & & $\begin{array}{l}0.254 * \\
(0.145)\end{array}$ & & $\begin{array}{c}1.172 * * * \\
(0.325)\end{array}$ \\
\hline${ }^{\text {a } D e n s i t y ~ s q u a r e d, ~} D E N^{2}$ & & $\begin{array}{c}-0.041 * * * \\
(0.014)\end{array}$ & & $\begin{array}{c}-0.115^{* * *} \\
(0.025)\end{array}$ \\
\hline Constant & $\begin{array}{c}16.300 * * * \\
(1.546)\end{array}$ & $\begin{array}{c}13.202 * * * \\
(1.909)\end{array}$ & $\begin{array}{c}17.802 * * * \\
(2.000)\end{array}$ & $\begin{array}{c}15.815^{* * *} \\
(2.998)\end{array}$ \\
\hline Autocorrelation & 0.0372 & 0.0368 & 0.0370 & 0.0366 \\
\hline Rho & 0.9814 & 0.9815 & 0.9814 & 0.9816 \\
\hline Chi-squared & 2.27 & 2.24 & 2.01 & 2.19 \\
\hline Countries & 59 & 59 & 59 & 59 \\
\hline Observations & 1239 & 1239 & 1239 & 1239 \\
\hline
\end{tabular}

Notes. ${ }^{\mathrm{a}}$ - used as $\log$ (variable); ${ }^{\mathrm{b}}$ — used as $\log (1+$ variable $) ;$ standard errors are in parenthesis; $* * *, * *, *$ — significant at 1,5 and $10 \%$ level (resp.).

Appendix A2. List of countries used in the study

\begin{tabular}{lll}
\hline \multicolumn{1}{c}{ High income (47) } & \multicolumn{1}{c}{ Upper Middle income (28) } & Lower Middle income (18) \\
\hline Austria, Australia, Bahrain, Barbados, Belgium, & Algeria, Argentina, & Bangladesh, Côte d'Ivoire, \\
Canada, Chile, Croatia, Cyprus, Czech Republic, & Botswana, Brazil, Bulgaria, & Egypt, El Salvador, Ghana, \\
Denmark, Estonia, Finland, France, Germany, & China, Colombia, Costa & Guatemala, Honduras, \\
Greece, Hong Kong, Hungary, Iceland, Ireland, & Rica, Dominican Republic, & India, Indonesia, Kenya, \\
Israel, Italy, Japan, South Korea, Kuwait, & Ecuador, Fiji, Iran, Jamaica, & Morocco, Pakistan, \\
Latvia, Lithuania, Luxembourg, Malta, The & Jordan, Kazakhstan, Lebanon, & Philippines, Sri Lanka, \\
Netherlands, New Zealand, Norway, Oman, & Malaysia, Mauritius, Mexico, & Tunisia, Ukraine, Vietnam, \\
Poland, Qatar, Saudi Arabia, Singapore, Slovakia, & Namibia, Panama, Peru, & Zimbabwe \\
Slovenia, Spain, Sweden, Switzerland, Trinidad & Romania, Russia, South & \\
and Tobago, United Arab Emirates, United States, & Africa, Thailand, Turkey, & \\
United Kingdom, Uruguay & Venezuela & \\
\hline
\end{tabular}

